\title{
Healthy Way of Living in the Extreme Climate Conditions of the Arctic
}

\author{
Zdravý způsob bydlení v extrémních \\ klimatických podmínkách Arktidy
}

\author{
Yekaterina Gninenko \\ Fakulta architektury, České vysoké učení technické v Praze, Česká republika \\ katerina.gninenko@gmail.com
}

\begin{abstract}
Development of the Arctic is necessary not only because of the mining of minerals or construction of scientific centres, but also due to the need to improve the quality of life of the local inhabitants. This can be achieved through architecture since it affects both work and personal lives of the inhabitants of the Arctic. The article deals with environmental aspects related to the issue of well-being Arctic architecture, its impact on public health and the search for sustainable solutions in the design of the fragile environment of the Far North.
\end{abstract}

KEYWORDS: well-being architecture; extreme natural conditions; Arctic

\begin{abstract}
ABSTRAKT: Rozvoj Arktidy je potřebný nejen z hlediska těžby nerostných surovin a stavby vědeckých center, ale také kvůli zvýšení kvality života místního obyvatelstva. Toho lze dosáhnout právě díky architektuře, která ovlivňuje jak pracovní, tak osobní život obyvatel Arktidy. Článek se zabývá ekologickými aspekty souvisejícími s problematikou well-being arktické architektury, jejím dopadem na veřejné zdraví a hledáním udržitelných řešení při projektování v křehkém prostředí Dálného severu.
\end{abstract}

KLÍČOVÁ SLOVA: well-being architektura; extrémní přírodní podmínky; Arktida 


\section{Úvod}

Extrémní prrírodní podmínky arktické oblasti se jeví jako vážná výzva pro architekty a stavitele. Při projektování staveb je nutné počítat s velkou řadou klimatických faktorů - silné nárazové větry, extrémně nízké teploty a rizika lavin - přinášejících nepředvídatelný charakter. Drsné podmínky počasí zvyšují zranitelnost člověka v místě jeho přirozeného prostředí a mají velký vliv jak na fyzický, tak i na emocionální komfort člověka. Projektování v podmínkách okrajových severských oblastí vyžaduje znalosti z multidisciplinárních oblastí - klimatologie, geologie, medicíny a dalších. Absence vazeb mezi různorodými profesemi může vést $\mathrm{k}$ chybám, neefektivitě a finančním ztrátám. Neméně důležité je také otevření dialogu mezi místní komunitou, staviteli, architekty a orgány místní vlády.

S rozvojem průmyslu se znalost arktické oblasti a její ekonomické aspekty stávají pro člověka stále potřebnějšími. Hovoříme např. o těžbě prrírodních bohatství, stavbě vědeckých observatoří a center studia klimatických změn a o vlivu globálního oteplování na oblast za polárním kruhem. Arktida je složité prostředí, v němž se rychle rozvíjejí ekonomika a sociální sektor (Glomsrød a Aslaksen, 2006) a které s rozvojem urbanizace potřebuje nový př́stup ke kvalitě života - zlepšení životních podmínek.

$S$ rozvojem vědy a technologií v Arktidě a následně s růstem počtu obyvatel rostou i nároky na komfort životních podmínek arktických obydlí. Článek je zaměřen na otázku zdravého komfortního bydlení pro dlouhodobé bydlení za polárním kruhem. V článku se vyskytuje termín well-being architektura jako architektura zabezpečující zdravý prostor pro bydlení a aktivity člověka, a to jak z fyziologického, tak z psychologického hlediska.

Cílem článku je přidat nový rozměr dané diskuzi a poukázat na nutnost dalšího výzkumu v oblasti projektování pro podmínky Dálného severu a stavění v těchto krajích, a to vše s cílem zvýšit kvalitu života obyvatelstva a podpořit trvale udržitelný rozvoj Dálného severu.

Světová zdravotnická organizace (WHO) říká, že „zdravé město“ neustále vytváří a zlepšuje fyzické a sociální prostř̌edí a rozšiřuje zdroje komunity, které lidem umožňují, aby se vzájemně podporovali při výkonu všech životních funkcí a aby rozvíjeli maximální potenciál ${ }^{1}$. Definice „zdraví“ člověka je neoddělitelná od pochopení „zdravého města“ a zahrnuje pochopení vztahu mezi sociálními, psychologickými a fyzikálními faktory. Zdraví nejenom znamená možnost př́stupu ke zdravotní péči, ale je také určováno řadou faktorů týkajících se kvality architektury životního prostředí (2). 
Pojem „trvale udržitelný rozvoj“ často zdůrazňuje jednotu fyzických, ekonomických a sociálních složek. Podle Vitruvia (Pollio, 2010) a jeho modelu složeného ze tř́ základních prvků je nezbytnou součástí správného projektování obydlí:

1. firmitas (pevnost, zdraví)

2. utilitas (komfort)

3. venustat (radost, štěstí)

Všechny tři výše uvedené základní prvky jsou nedílnou součástí pojetí well-being architektury, která je nyní stále populárnější i v arktických oblastech. Jestli dříve byla architektura zaměřena především na přežití obyvatelstva $\mathrm{v}$ podmínkách extrémně chladného počasí, dnes se role obydlí jako ochrany před okolním prostředím stává nedostatečnou - objevují se nové požadavky na zdravý a sociálně aktivní život obyvatelstva i na tělesné a duševní zdraví. Smyslem dnešní moderní architektury Arktidy je nejen „chránit člověka a oddělit ho“ od prŕrody, ale naopak také přispět k životu v harmonii s prŕrodou Arktidy a jejími obtížnými klimatickými podmínkami.

Mezi hlavní problémy, s nimiž se setkávají obyvatelé Dálného severu, je možné zařadit nedostatečné sluneční záření, chlad, nezvyklé kvantum světelné energie (nedostatek nebo přebytek světla), zvýšené zatížení větrem, vysokou vlhkost vzduchu $\mathrm{v}$ teplých a přechodných obdobích roku, nižší vlhkost v atmosfére v mrazivých dnech, zvýšené radiace a elektromagnetické záření (3).

Základní přírodní faktory, které ovlivňují architekturu za polárním kruhem, a jejich řešení shrnuje tabulka č. 1 .

V současné době je v porovnání s předchozími generacemi velký rozdíl v lidském vztahu k př́rodě. Například děti tráví mnohem méně času hraním her v př́rodě (4). Obecně platí, že jednotlivci z rozvinutých zemí tráví 90 \% času v uzavřených prostorách. V chladném podnebí je toto číslo ještě vyšší; ve Finsku lidé v zimním období tráví venku jen asi $4 \%$ času (Ronkko, 2014). Nedostatek spojení člověka s př́rodou v polárních oblastech má negativní vliv na jeho psychickou pohodu (well-being). Vliv přírody na život člověka je úzce spojen s celkovou emoční spokojeností člověka (4).

Úkoly moderní architektury Arktidy - co nejvíce smazat hranice mezi př́rodním a umělým, a to $\mathrm{v}$ rámci toho, co dnes umožňuje vývoj strojírenských technologií pro život v drsných podmínkách. Podle A. K. Sidorova: „... největší profesionální zájem pro vědu a praktické architektonické problémy v Arktidě představuje ustanovení finálního poměru mezi př́rodou a umělou tvorbou. Takový př́klad finálního vývoje architektonických prostorových řešení a maximální doby, kdy osoba bydlí v umélém prostředí v nejdrsnější oblasti severní polokoule Země, prèdstavuje Dálný sever a ark- 
tické oblasti - pobřeži moří Severního ledového oceánu ... iluze zveličování umělých životních podmínek a nezávislosti člověka na př́rodním prostředí je rozptýlena..." (4).

Jak je dobře známo, místní prŕroda má vliv na fyzický stav i psychiku člověka. Fyzický stav člověka je ovlivněn především klimatickými projevy. Duševní stav závisí na mnohonásobně více faktorech okolního prostředí a kromě jiného také na adaptivitě člověka. Takovými typickými faktory jsou u arktické oblasti monotónní krajina, ticho, absence zeleně a deformace perspektivy prostorových vzdáleností z důvodu ploché krajiny sněhových závějí, tzv. efekt white-out, často způsobující duševní nepohodlí uživatelů. Dalšími problémy ve vztahu ke zdraví obyvatel jsou polární den a polární noc. Jak uvádějí v nápise v chrámu Diany u Efezu antičtí architekti: „Slunce dává svými paprsky život.“ Nikde jinde tato věta nenese tak hluboký význam jako na Dálném severu, kde člověk nevidí slunce po dobu dlouhých polárních nocí a polárních soumraků (5) - toto má prrímý vliv na psychiku lidí: člověk trpí bolestmi hlavy, únavou či hypersomnií. Proto je další podmínkou pro vytvoření pohodlného lidského života na Dálném severu maximální využití solární energie u budov, kde lidé žijí a pracují, a u oblastí, kde odpočívají. V současné době jsou však jako norma v praxi architektonicko-urbanistického plánování na Dálném severu většinou brány $\mathrm{v}$ úvahu pouze údaje o klimatu (4). Úkolem moderní architektury v těchto regionech je nejenom řešit klimatické faktory ve stavebnictví, ale také reagovat na psychologický a sociální stav člověka a na jeho psychickou spokojenost jako nedílnou součást komfortního well-being prostředí.

Řešení výše uvedených problémů well-being prostředí se odráží v řadě projektů pro drsné klima. Hlavní myšlenkou většiny návrhů byla potřeba přizpůsobit život obyvatel tak, aby nezávisel na dopadu nepříznivého vnějšího prostředí, ale zároveň aby byl člověk obklopen př́rodou - parky či zahradami.

Např́íklad Alexander Bolonkin, specialista v oblasti kosmu, a Richard Cathcart, geograf, nabídli, že postaví bezrámovou „věčně zelenou kupoli pro polární oblast“ (Evergreen Polar Zone Dome - EPZD) v napnutém stavu. Napnutí je způsobeno nadměrným tlakem uvnitř kopule, nikoliv tlakem ve dvouvrstvém plášti, jak se často používá u nafukovacích stavebních konstrukcí.

Vědci navrhli, aby na straně kupole obrácené k nízkému slunci byly upevněny tenké regulovatelné rolety a aby z vnitřní strany kupole, na straně proti slunci, byla nanesena tenká hliníková fólie (tlouštka 1 mikrometr), která by odrážela paprsky dolů (Bolonkin a Cathcart, 2011).

Na podobné membránové technologie byl v roce 2014 ruskými architekty navržen unikátní projekt arktického města „Umka“ - města pod kopulí. Projekt byl založen 
na myšlence nastolení harmonického vztahu člověka a vnitřního i vnějšího životního prostředí tím, že bude vytvořen jediný přirozený ekosystém.

Z realizovaných nápadů well-being architektury je třeba zmínit projekt architekta Aaltoa - mistra práce s přirozeným světlem v podmínkách nedostatku světla na Dálném severu. Vyvinul metodu šíření přirozeného světla - od střešních oken ve válcovém tvaru v městské knihovně Viipuri v Rusku (1927-1935) po velké dvouvrstvé skleněné hranoly v Národním penzijním ústavu v Helsinkách (1948, 1952-1957), (Decker, 2010).

\section{Závěr}

Na základě klimatických modelů a výpočtů došli výzkumníci v oboru klimatu k závěru, že životaschopné prostředí určené $\mathrm{k}$ bydlení člověka bude $\mathrm{v}$ příštím století zaměřeno na zemské póly (Decker, 2010). Integrování principů plánování v oblasti udržitelného rozvoje severních oblastí a principů well-being architektury jistě vyžaduje další studii, protože v blízké budoucnosti bude v polárních oblastech nevyhnutelná radikální sociální a ekonomická změna. Je třeba dále studovat myšlenku komplexního př́stupu k projektování Dálného severu se všemi fyzickými a psychologickými aspekty trvalého bydlení člověka v náročném klimatickém prostředí, tj. ochranou životního prostředí, zlepšením kvality života obyvatel a zachováním přírodních zdrojů, to vše za účelem ochrany zájmů budoucích generací.

\begin{tabular}{|l|l|l|}
\hline & Parametry & Způsob řešení \\
\hline Tepelný komfort & Extrémně nizké teploty, dlouhé zimni období & $\begin{array}{l}\text { Systémy topení, tepelné izolace, } \\
\text { obalové plášté budov }\end{array}$ \\
\hline Osvětlení & $\begin{array}{l}\text { Nedostatek světla v období polárních nocí, } \\
\text { nadbytek světla v období polárních dní }\end{array}$ & $\begin{array}{l}\text { Systémy umělého osvětlení, systémy } \\
\text { stínění }\end{array}$ \\
\hline Kvalita ovzduší & $\begin{array}{l}\text { Zvýšená vlhkost vzduchu v letním období, } \\
\text { snížená vlhkost vzduchu v zimním období }\end{array}$ & Ventilační a čistící systémy ovzduší \\
\hline Vizuální komfort & $\begin{array}{l}\text { Ohraničení a monotónnost krajiny, } \\
\text { nedostatek veřejných zelených ploch - parkủ, } \\
\text { nedostatek nep̌etržitém kontaktu mezi } \\
\text { člověkem a přirodou, white out efekt z } \\
\text { důvodu sněhových závěji - ztráta horizontu }\end{array}$ & $\begin{array}{l}\text { Použití zelené barvy v architektuře a } \\
\text { dřeva, stavba zimnních zahrad v interiéru }\end{array}$ \\
\hline
\end{tabular}

Tab. 1. Přírodní faktory ovlivňující architekturu za polárním kruhem. (Zdroj: vlastní zpracování autorem) 


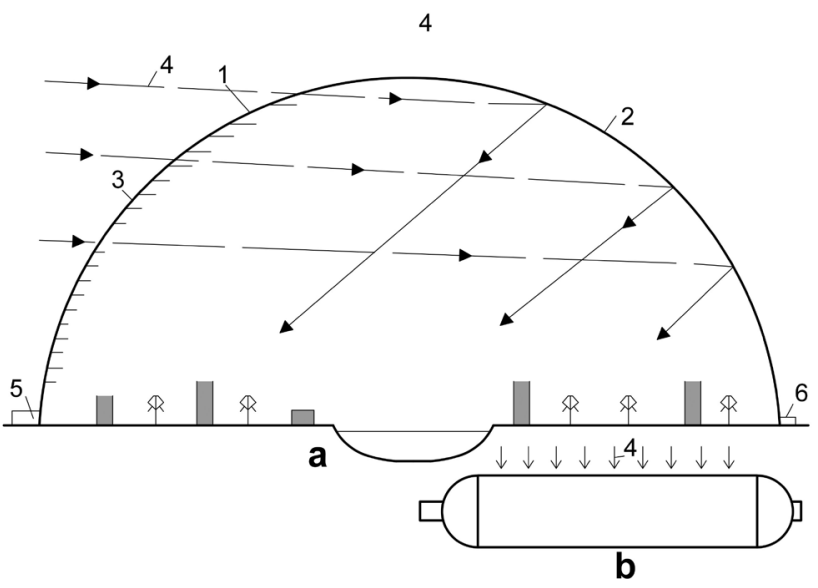

Obr. 1. Nafukovací kupole pro chladné oblasti severní hemisféry. Poznámky: (a) prríčný řez; (b) půdorys, (Zdroj: Inflatable 'Evergreen' Polar Zone Dome (EPZD) Settlements Alexander A. Bolonkin, Richard B. Cathcart)

\section{Poznámky}

1. Healthy city is 'continually creating and improving the physical and social environments and expanding the community resources that enable people to mutually support each other in performing all the functions of life and in developing to their maximum potential.'

2. Future health: Sustainable places for health and well-being. In: Commission for Architecture and the Built Environment (CABE) [online]. London: nationalarchives.gov.uk, 2009 [cit. 2016-09-11]. Dostupné z: http://webarchive.nationalarchives.gov.uk/20110118095356/http:/www.cabe.org.uk/publications/future-health

3. Влияние глобальных климатических изменений на здоровье населения Российской Арктики. In: Публикация подготовлена коллективом для Представительство ООН в Российской Федерации [online]. Москва: http:// www.ecfor.ru/ [cit. 2016-09-11]. Dostupné z: http://www.ecfor.ru/pdf.php?id=books/revich01/oon

4. Экология человека в Арктических условиях. In: Вестник Алтайского государственного технического университета им. И.И. Ползунова № 1-2 2009 [online] [cit. 2016-09-11]. Dostupné z: http://www.instu.ru/pg-172.html

5. Концепция архитектуры города-спутника в условиях прибрежных территорий Арктики [online] In: http://sci-article.ru/ [cit. 2016-09-11]. Dostupné z: http://sci-article.ru/stat.php?i=1432828397 
28 6thACAU 2016 conference papers

\section{Prameny}

Glomsrød, S. Aslaksen, I. The economy of the North. Oslo, Norway, 2006. ISBN 8253771118

POLLIO, Marcus Vitruvius. Deset knih o architektuře. Praha: TeMi CZ, 2010. ISBN 80-86410-23-4.

RONKKO, E. Actions on urban health enhancement in the Arctic: Salutogenic Planning concept. Oulu, Finland, 2014. ISBN 9789526206356.

BOLONKIN, A. CATHCART, R. Inflatable ‘Evergreen' Polar Zone Dome (EPZD) Settlements [online] In: arxiv.org [cit. 2016-09-11]. Dostupné z: https://arxiv.org/ abs/physics/0701098

DECKER, J. Modern North : Architecture on the Frozen Edge. New Yourk, 2010. ISBN 9781568988993. 